Citation: Agaj Avdiu, T., Qamıl1, S., \& Avdiu, A. (2021). The impact of the faculty of education in preparing its graduates for the implementation of the new school curriculum. International Journal of Scholars in Education, 4(1), 119-132. doi: 10.52134/ueader.904388

\title{
The Impact of the Faculty of Education in Preparing its Graduates for the Implementation of the New School Curriculum
}

\author{
Teuta AGAJ AVDIU*, Shpresë QAMILI**, Arsim AVDIU***
}

\begin{abstract}
The implementation of the curriculum is expected to give a push to an increasing quality of managing and processing educational efforts towards betterments at every unit of learning and education. Applying a new curriculum, namely implementation of 2017 Curriculum at schools in Kosova has been commenced in September 2017. This study examined the impact of the Faculty of Education in preparing its graduates for the implementation of the new school curriculum with reference to University "Kadri Zeka" in Gjilan, Kosova. The purpose of this study is to investigate the graduate students' preparedness to implement the new school curriculum. The quantitative method has been employed for this research. A questionnaire for graduate students has been used to collect data. 81 graduate students filled out the online questionnaire. The results from this research indicate that the graduates of the University "Kadri Zeka", respectively the graduates who were prepared in primary and preschool programs felt significantly prepared across most dimensions of teaching. However, there is room for improvement regarding the new school curriculum implementation.
\end{abstract}

Keywords: "Kadri Zeka" University, the New curriculum, Teaching, Implementation, Preparedness, Graduate students' responses.

\footnotetext{
Assist. Prof. Dr, Public University “Kadri Zeka “, Gjilan, Kosovo, ORCID: 0000-0003-1992-5946, e-mail: teuta.agaj@uni-gjilan.net

Assist. Prof. Dr, Public University “Kadri Zeka “, Gjilan, Kosovo, ORCID: 0000-0001-5417-563X, e-mail: shpresa.qamili@uni-gjilan.net

PhD. Cand, Primary School "Hasan Alia”, Vitia, Kosovo, ORCID: 0000-0001-8391-9810, e-mail:

arsim avdiu89@hotmail.com
} 


\section{Introduction}

A country with quality education has the strongest weapon of the XXI century, based on this fact large investments for the development of this field are present not only in Kosova but in all countries. The education sector in Kosova is characterized by continuous efforts towards reforming all sub-sectors that address the key challenges of increasing participation and improving quality in education. We are witnessing various developments that have been made in the curricula, so that our education is comparable to the education of developed countries. The first step in reforming pre-university education is the drafting of the Curriculum Framework.

In 2011, the MEST approved the Pre-University Education Curriculum Framework in Kosovo in order to establish a regulatory framework for pre-university education reform. In 2016, after the second phase of the pilot, MEST issues a revised version of this document entitled Curriculum Framework for Pre-University Education in Kosovo. (Boshtrakaj, Rraci, \& Bajrami, 2018)

The innovations of the new curriculum are: access to competencies and learning outcomes, reorganization of curricular areas and main levels of the curriculum, teaching and learning methodology, assessment of student achievement, reorganization of the elective curriculum, and other aspects of organization at school level. (MEST, 2017)

\section{Literature Review}

Education is the process of human formation, universal formation of the positive, intellectual and emotional qualities of the human. It is the process of building positive character traits and shaping the personality of the free man and comprehensive development. If we look at it more broadly, education involves the whole process of developing and shaping the personality of the young person. This means that the function of education includes not only educational work in school and in the family, in organizations of children and youth and in social organizations, but also the influence of lifestyle, social views, literature, media, cultural institutions and other factors (Shimillesha,1988).

The curriculum as a field of study is characterized as incomprehensible, fragmented and confused. Of course, it can sometimes have all of these, but we need to be aware that the curriculum as a field of study is crucial to the well-being not only of schools but of society as a whole. If we evaluate the curriculum in a narrow sense of the field as a list of subjects that should be taught in school, but also in a broad sense of the experiences that individuals require for full and real participation in society, it is not denied that the curriculum affects everyone, that is, both those who deal with this field, teachers and curriculars of different fields, as well as society in general (Dervodeli, 2010).

To facilitate the process of understanding this notion, we will start with the etymology of the word Curriculum. The word curriculum derives from the Latin word 'Curricullum' which means life program (Hyseni, 2005).

The curriculum can be defined as an action plan or a written document that includes strategies for achieving the desired objectives or goals. This point of view spread by Tyler and Taba represents a linear view of the curriculum. The order of the planner's steps is predetermined. The plan has a beginning and an end as well as a process and a mechanism, in order that what starts, progresses and ends. However, the curriculum can be broadly defined as the area that addresses the student's experiences. This view calls everything inside the school and even outside it (as long as it is planned) part of the curriculum. It has the roots in Djui's definition of experience and education, as well as in the view of scholars Kasuell and Kemellne 
in the 1930s, that the curriculum represents "all the experiences that students gain under the guidance of teachers" (Dervodeli, 2010).

The priorities of the curriculum are: the increase of the importance and quality of learning, the increase of the student outcomes, the improvement of the integration in learning areas, the improvement of the implementation strategies (Nishku et al., 2006).

The core curriculum for the pre-primary grade and primary education, along with other curricular documents, make applicable the Pre-University Education Curriculum Framework, approved by the MEST, in August 2016. This document defines the results for competencies and results for curriculum areas, expressed in knowledge skills, attitudes and values that should be developed and achieved by students by the end of certain time periods as well as the methodological approach of implementation, including teaching, learning and evaluation. This document also defines the distribution of teaching time (lessons) for curriculum areas and their interconnection which enable progress in the development of student competencies (MEST, 2016a; MEST, 2016b; MEST, 2016c).

According to Mehmeti, Buleshkaj \& Lynn, (2013) the necessary changes in the curriculum are addressed in three different ways:

1. From focus on subjects to focus on learning outcomes and competency-based

2. From teacher-centered focus to student-centered focus

3. From didactic / teaching methodology to a more interactive and comprehensive methodology.

The full implementation of the new state curriculum, respectively the reform in preuniversity education is achieved only when:

-Teachers fully understand and accept the new spirit of the curriculum and its activities return to routine,

-The school is constantly committed to improving the teaching and learning process towards raising the level of students' achievement,

-Schools and municipal directorates of education engage in an ongoing process of collecting and analyzing data, identifying challenges and finding solutions to summarize the requirements of the new state curriculum system.

-MEST monitors the fulfillment of curriculum requirements at the state level, as a basis for providing the necessary institutional support (Kosovo Pedagogical Institute, 2016).

To assess students according to the competency-based curriculum, it is important to establish assessment techniques that enable students to demonstrate not only their knowledge but also their skills and attitudes (MEST, 2013).

Some pedagogues, using the notion "teaching technology", unjustly identify its content with the "educational technique" or in the narrowest sense with what is meant by "teaching tools", namely audio-visual media. Other pedagogues with the notion "technique" mean the teaching techniques, methods, actions and forms of teaching work while the content of the notion "teaching technology" is based on the process of organizing learning according to contemporary requirements by using contemporary tools. From this, which was pointed out above, it can be said that the definition of the meaning of the notion "technique" and "technology" is correct. Although there are dilemmas about their explanation, it is still true that these two notions differ from each other as does the character of their application in teaching work (Vojka-Ismajli, 2012).

Learning works and the basic tasks (functional and educational materials) are effectively accomplished through the theoretical aspect, observation of lessons and finally 
through the practical aspect. It results that the teaching practice is realized after the theoretical teaching and the classroom observations. It is therefore rightly said that the classroom observation is considered as a bridge that connects theoretical learning with practical learning (Haliti, 2004).

The first purpose of practical learning is for students to develop certain knowledge, skills and attitudes to be educators at the primary and pre-school level. This includes developing the skills to create and manage a cultivating and supportive environment of learning and play and to plan and implement the curriculum that suits children's development (University of Prishtina, 2004).

Being aware of the need for the best possible training of teachers at both first levels of the education system in Kosova, University "Kadri Zeka" respectively the Faculty of Education aims at training teachers who will be the stimulating force for further development of teaching practice in Kosova. The graduates of the Faculty of Education acquire knowledge and competences from general, academic and didactic-methodological courses. These competences include: knowledge in their respective subject (academic knowledge), needed reflection and professional capacities to solve problems; learning of communication and group work with other professionals in education; holistic conception with children and youngsters; familiarization with and understanding developing characteristics of school children; understanding the differences of pupils' needs, etc (University of Kadri Zeka, 2016).

On completion of the studies, students will be able to: dismantle the curriculum into activities planned for children, orienting their work according to the approach with the child in the center; organize educational activities aiming at achieving learning outcomes, provided by the Kosovo Curriculum Framework, according to the respective fields (University of Kadri Zeka, 2021).

\section{Research Methodology}

The topic of this research paper has been studied in terms of theory as well as in terms of practice. Regarding the theoretical aspect, various literature related to this issue has been analyzed and explored, whereas regarding the practical aspect, a special attention has been paid to the impact of the Faculty of Education of the "Kadri Zeka" University in preparing its graduates for the implementation of the new school curriculum. To fulfill our objectives, this research has been carried out using the quantitative method through which the necessary data have been collected to reflect the preparedness of graduate students for the implementation of the New Curriculum. The quantitative method serves as a form of collecting numeral data. As Question Pro (2020) states "Quantitative research collects information from existing and potential customers using sampling methods and sending out online surveys, online polls, questionnaires, etc., the results of which can be depicted in the form of numerical." Data has been collected through a questionnaire for graduate students. In order to avoid misunderstandings, the questions have been written in both languages, English and Albanian.

\section{Aim and importance}

The implementation of the New Curriculum remains one of the main tasks of teachers that requires adequate professional training, methodological and pedagogical skills, as well as in-depth knowledge of the content of the New Curriculum. Therefore, the major objectives of this research are:

- to assess the preparedness of the graduate students of the "Kadri Zeka" University respectively Faculty of Education in implementing the Kosovo new school curriculum; 
- to see whether the Faculty of Education of University "Kadri Zeka" prepares its graduates to implement the new school curriculum;

- to reveal the program courses that best help in training and developing students professionally;

- to show the graduate students' evaluation of the study program compatibility with the teaching process.

\section{Research Questions}

This study will seek to answer the following research questions:

1. Are the "Kadri Zeka" University graduate students of preschool and primary program all set to implement the new school curriculum in their teaching?

2. Is there sufficient and adequate literature to equip students with knowledge in the implementation of the new Kosovo curriculum?

3. Does the practice in schools-preschool institutions help students in implementing the new school curriculum?

\section{Data Gathering Procedure}

In order to collect data related to the impact of the Faculty of Education of the "Kadri Zeka" University in preparing its graduates for the implementation of the new school curriculum, the graduate students' questionnaire has been used. It is thought that University "Kadri Zeka" graduates can best assess their preparedness or unpreparedness to work according to the new school curriculum and thus provide more complete, convincing and concrete results. The graduate students' questionnaire contains nine questions. For the questionnaire validity, opinions of two academicians of education field were taken. Questionnaire is generally considered to be high in reliability as it is composed of closed questions. The graduate students were required to answer the questionnaire by ticking the appropriate box. The data obtained from the research has been presented in graphs and the results of the research has been presented through them.

\section{Participants}

To provide the most accurate and qualitative data and to make this research more beneficial, our research participants comprise 81 graduate students of University "Kadri Zeka" who completed their studies in the Faculty of Education respectively preschool or primary program during different academic years. The graduate students have been selected because it is presumed that they have acquired substantial amount of knowledge and skills for teaching including implementing the new school curriculum. The questionnaire has been submitted online.

\section{Results}

Regarding the results of the questionnaire, a total of 9 questions were used to measure the impact of the Faculty of Education in preparing its graduates for the implementation of the new school curriculum. Graduate students of the University "Kadri Zeka" in Gjilan, Kosova were asked to evaluate through the Likert scale, except in some cases where other response options were used. The responses received from the research group consisting of 81 graduates have provided considerable help in highlighting the real data on the topic chosen for research. The results of the questionnaire have been analyzed and are presented in more details below. 


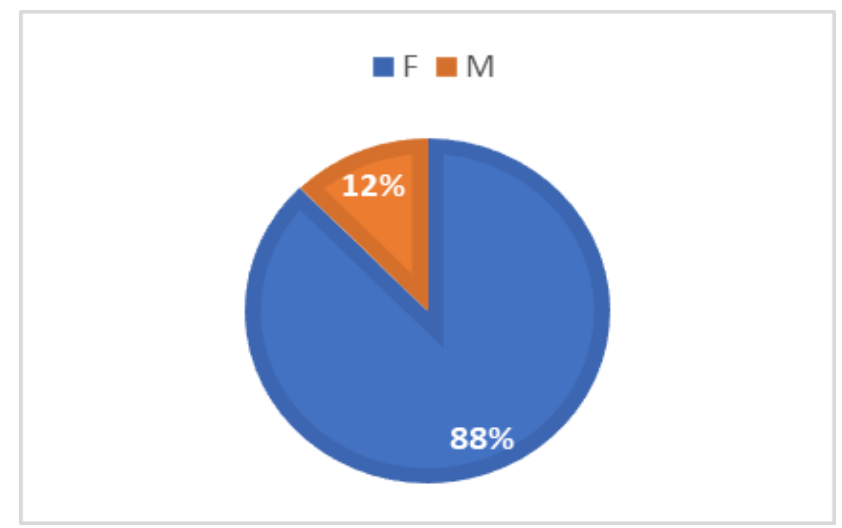

Figure 1. The data for the gender of the graduates

Based on Figure 1, out of $81(100.0 \%)$ participants in the research, $71(88 \%)$ were female and $10(12 \%)$ were male.

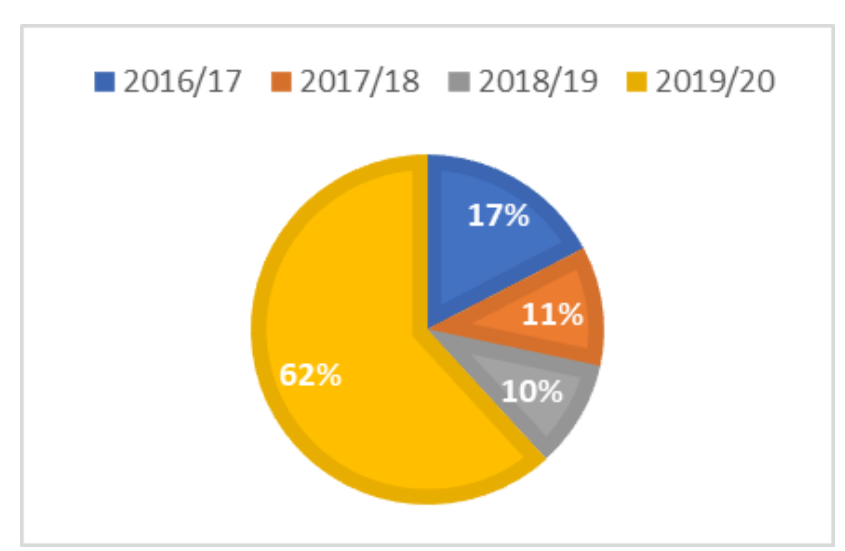

Figure 2. The data for the graduation time

Regarding the graduation time of the participants, $50(62 \%)$ of them graduated in the academic year 2019/20, $14(17 \%)$ in the 2016/17 academic year, $9(11 \%)$ in the $2017 / 18$ academic year and $8(10 \%)$ in the academic year 2018/19.

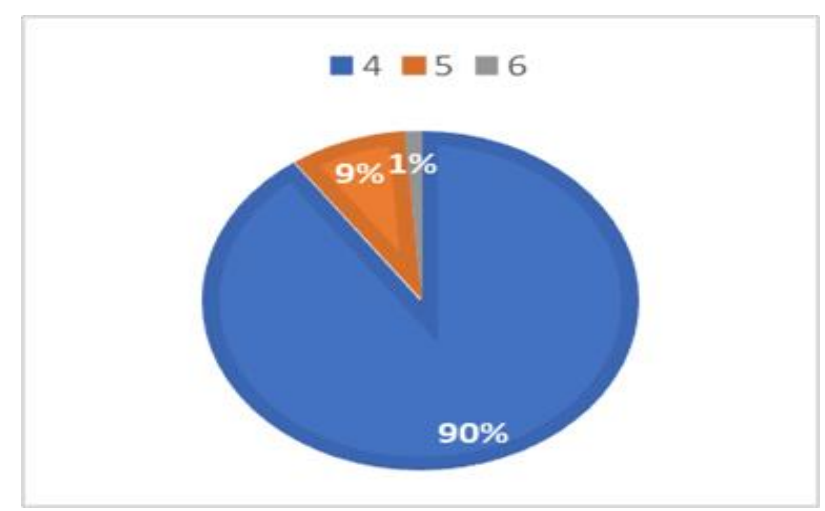

Figure 3. The data for the duration of studies

Figure 3 shows that the studies of 73 (90\%) graduate students lasted 4 years, 7 (9\%) 5 years and $1(1 \%) 6$ years. From the table, it can clearly be seen that most of the participants had completed their studies on time. 
The Impact of the Faculty of Education in Preparing its Graduates for the Implementation of the New School Curriculum

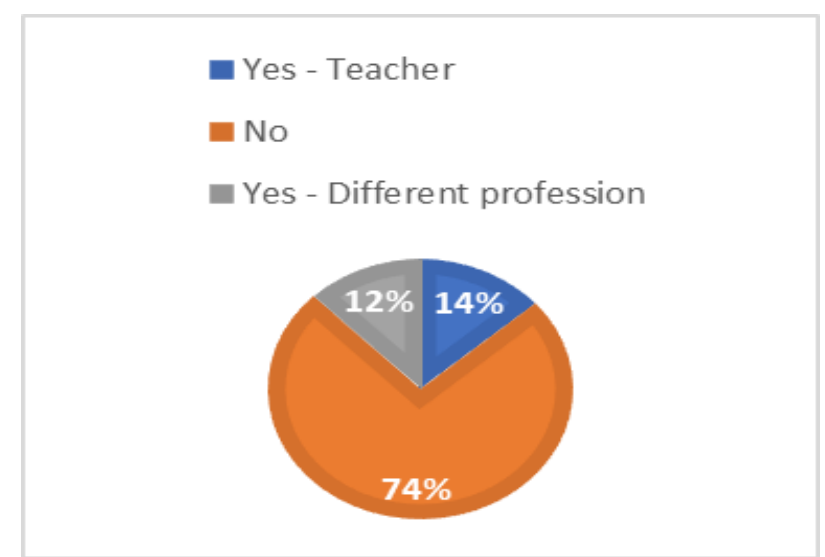

Figure 4. The data for the employment of the graduates

With reference to the results from figure 4 , it can be seen that $60(74 \%)$ of participants are unemployed, $10(12 \%)$ are employed in the teaching profession whereas $11(14 \%)$ of participants work in different fields.

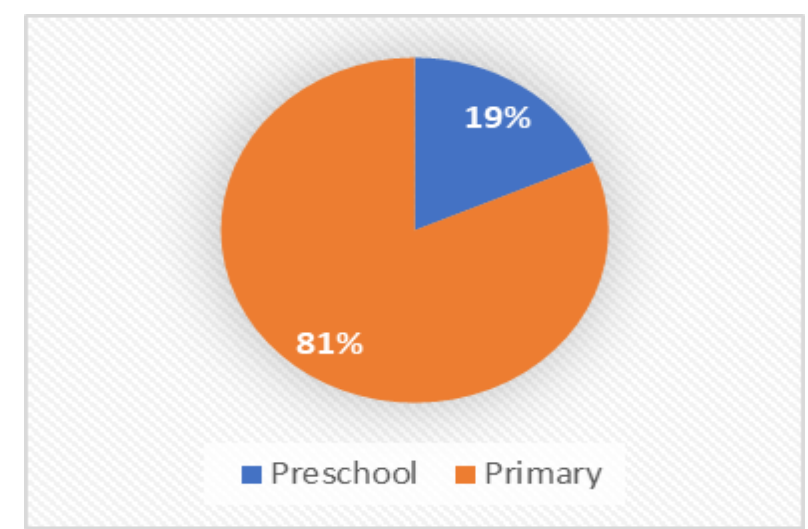

Figure 5. The data for the program of studies

The above figure shows that the questionnaire was filled out by $66(81 \%)$ graduates of the primary program and $15(19 \%)$ graduates of the preschool program.

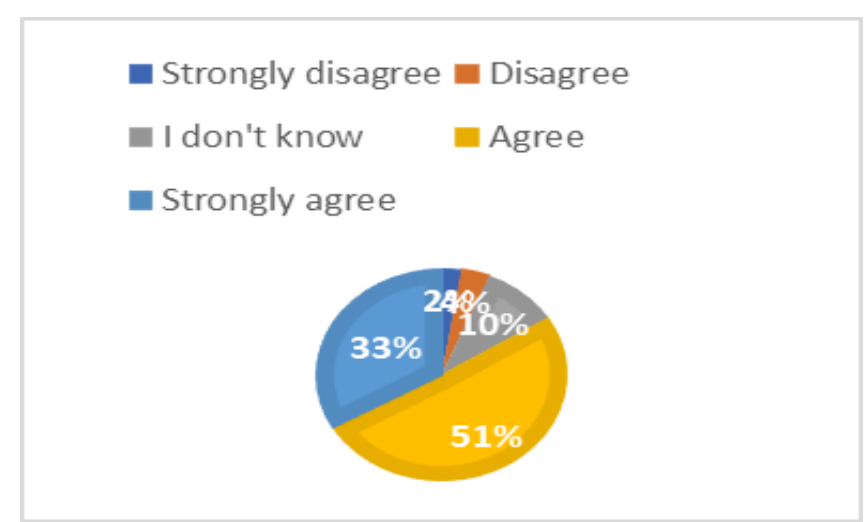

Figure 6. The research results for the statement: Studies at the UKZ Education Faculty helped me to develop key competencies for the teaching process.

Figure 6 presents the data for the statement: Studies at the UKZ Education Faculty helped me to develop key competencies for the teaching process. $41(51 \%)$ of graduate students 
answered: I agree; 27 (33\%) answered: I strongly agree; 8 (10\%) answered: I don't know; 3 (4\%) answered: I disagree; and $2(2 \%)$ answered: I strongly disagree.

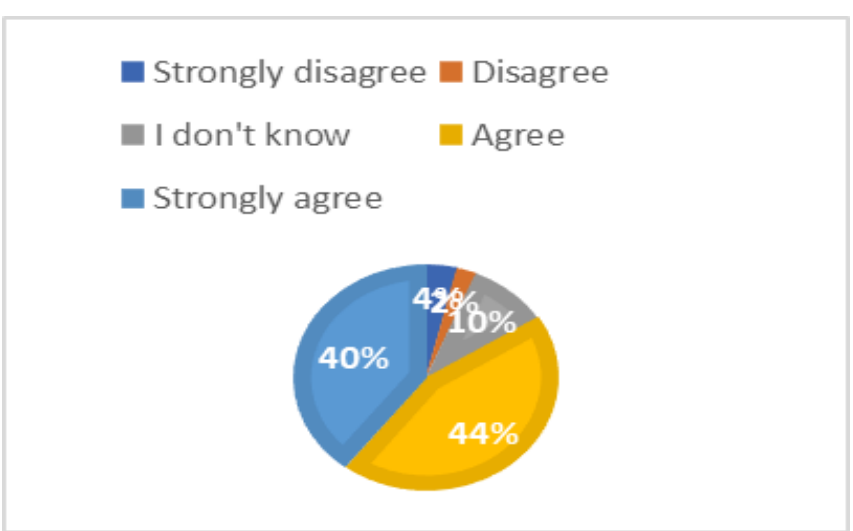

Figure 7. The research results for the statement: The duration of studies for the preparation of preschool / primary teachers enabled my preparation as a teacher

Regarding the statement: The duration of studies for the preparation of preschool / primary teachers enabled my preparation as a teacher. We received the following responses from the graduates: $36(44 \%)$ responded: I agree; $32(40 \%)$ responded: I strongly agree; $8(10 \%)$ responded: I don't know; 2 (2\%) responded: I disagree; and 3 (4\%) responded: I strongly disagree.

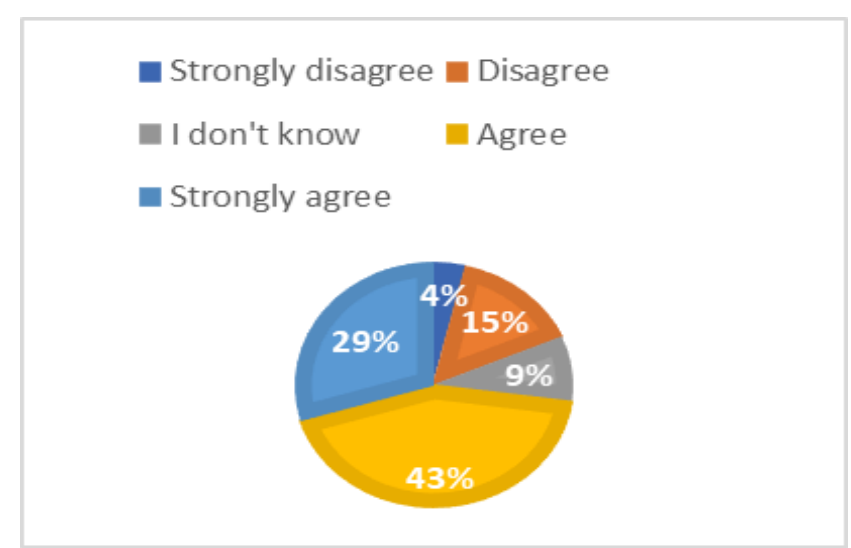

Figure 8 . The research results for the question: Do you think that the study program offered by the faculty has prepared you for the labor market?

The opinions of the graduates on the question: Do you think that the study program offered by the faculty has prepared you for the labor market? can be seen in Figure 8: 35 (43\%) agreed; 24 (29\%) strongly agreed; 7 (9\%) did not have an opinion on the question; 12 (15\%) disagreed; 3 (4\%) strongly disagreed. 
The Impact of the Faculty of Education in Preparing its Graduates for the Implementation of the New School Curriculum

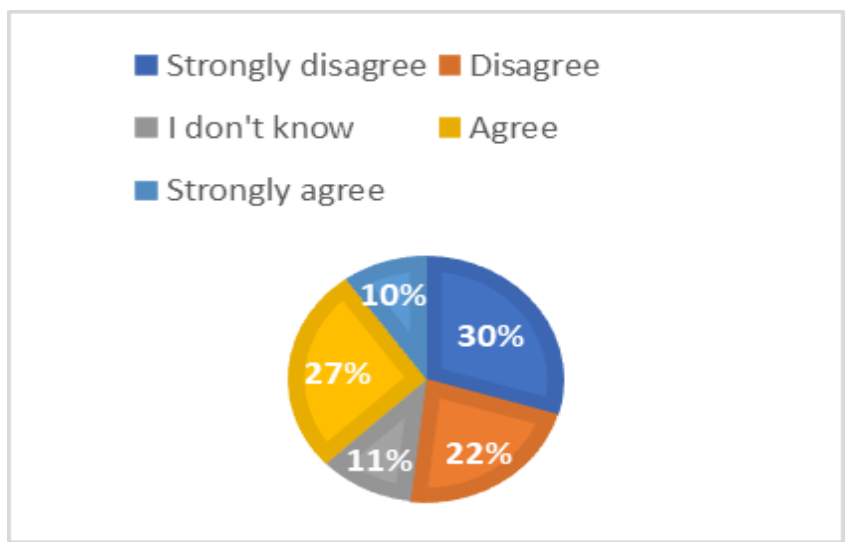

Figure 9. The research results for the statement: The study program has provided me with key competencies from the Kosovo Curriculum Framework - KCF

In Figure 9 are shown the answers of the statement: The study program has provided me with key competencies from the Kosovo Curriculum Framework - KCF. 22 (27\%) of the responding graduates said: I agree; 24 (30\%) said: I strongly disagree; 18 (22\%) said: I disagree; 9 (11\%) said: I don't know; and 8 (10\%) said: I strongly agree.

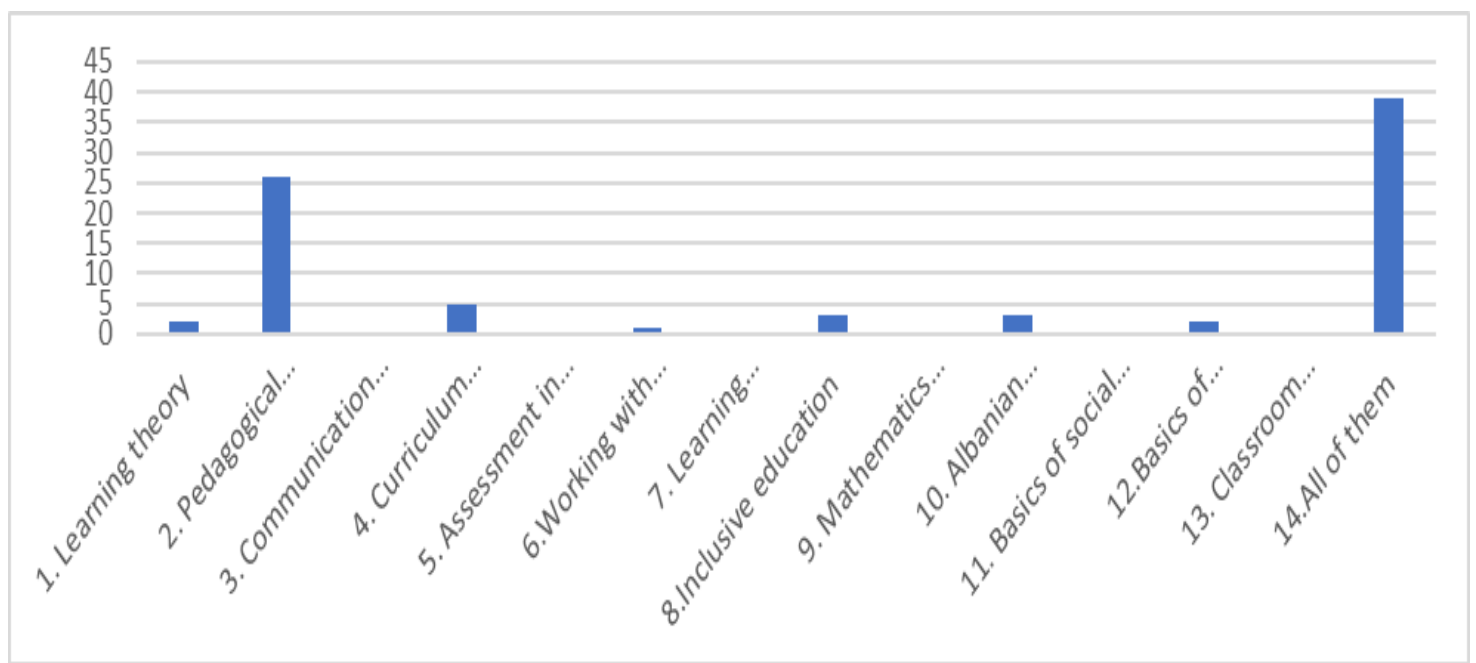

Figure 10. The research results for the question: Which of the study program courses are the main courses of your training and professional development?

Regarding the graduates' responses on the question: Which of the study program courses are the main courses of your training and professional development? Figure 10 shows the following results: 39 (48.1\%) chose the option: all of them (all the courses listed under the question); 26 (32.1\%) chose the course: Pedagogical practice; 3 chose: Inclusive education; 3 : Albanian language methodology; 2: Learning theory; 2: Basics of natural sciences with methodology; and 1: Working with Gifted and Talented Children. 


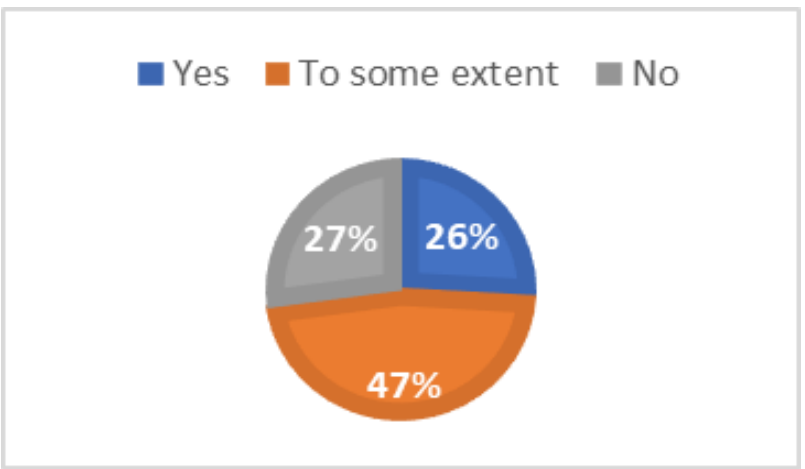

Figure 11. The research results for the question: Do you think that the above-mentioned courses are sufficient for your preparation in the implementation of the Kosovo Curriculum Framework - KCF?

Do you think that the above-mentioned courses are sufficient for your preparation in the implementation of the Kosovo Curriculum Framework - KCF? Graduates' answers to this question are shown in figure 11; $38(47 \%)$ said: to some extent; $21(26 \%)$ said: yes; and 22 (27\%) said: no.

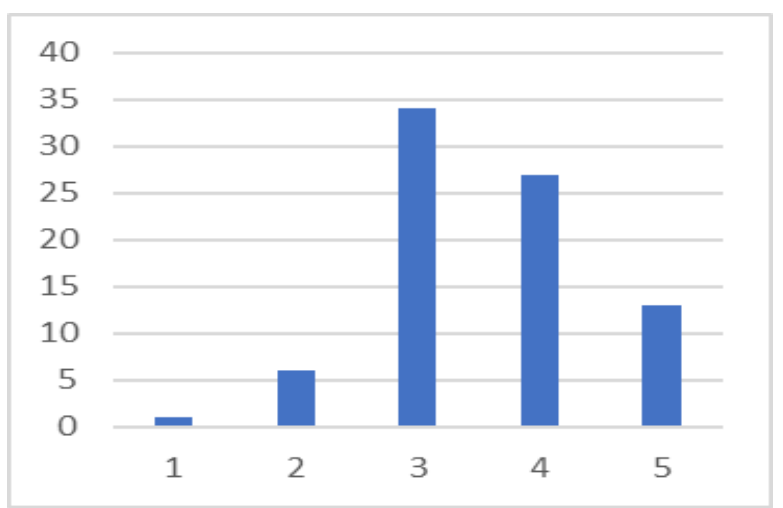

Figure 12. The research results for the question: What is your overall evaluation of the quality of the study programs you have attended / completed? $-1=$ worst; $5=$ best.

Regarding the quality of the study program, $34(42 \%)$ of graduates evaluated it with the grade $3 ; 27(33.3 \%)$ with the grade $4 ; 13(16 \%)$ with the grade $5 ; 6(7.4 \%)$ with 2 ; and $1(1.2 \%)$ with 1 .

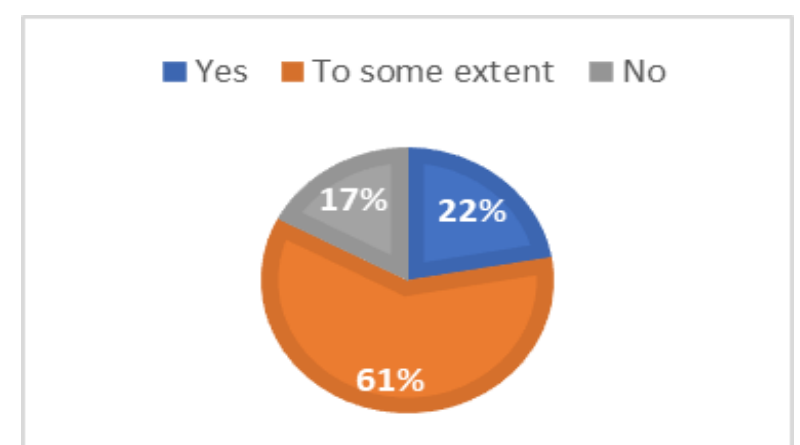

Figure 13. The research results for the question: Is the literature used by the professors appropriate for your training and professional development? 
As it can be seen in figure 13, the results of the question: Is the literature used by the professors appropriate for your training and professional development? are: $49(61 \%)$ of the graduates answered: to some extent; 18 (22\%) answered: yes; and 14 (17\%) answered: no

\section{Discussion}

In this section of this study, it is important to compare and contrast the findings with the literature review. The results of this research paper indicate that studies at the UKZ Education Faculty help students to develop key competencies for the teaching process. The majority of the graduate students chose agree and strongly agree as shown in figure 6 . This result is consistent with UKZ self-evaluation report (2016) stating that the graduates of the Faculty of Education acquire knowledge and competences from general, academic and didactic-methodological courses.

According to University "Kadri Zeka" (2021) its graduate students are able to dismantle the curriculum into activities planned for children, orienting their work according to the approach with the child in the center as well as organize educational activities aiming at achieving learning outcomes, provided by the Kosovo Curriculum Framework, according to the respective fields. Yet, the opposite of this resulted in this research paper, figure 9 shows that when students were asked whether the study program has provided them with key competencies from the Kosovo Curriculum Framework 22 (27\%) of the responding graduates said: I agree; 24 (30\%) said: I strongly disagree; 18 (22\%) said: I disagree; 9 (11\%) said: I don't know; and 8 (10\%) said: I strongly agree. The reason is that graduate students of the University "Kadri Zeka" who participated in this research completed their studies before the last re-accreditation process in which significant changes have been made with regard to the new school curriculum. The course pedagogical practice help students develop certain knowledge, skills and attitudes to be educators at the primary and preschool level (University of Prishtina, 2004). Similarly, this research paper concludes that primary and preschool programs' courses respectively pedagogical practice are the main courses of students' training and professional development.

\section{Conclusions and Suggestions} drawn:

Based on the abovementioned findings of the study, the following conclusions are

University "Kadri Zeka" respectively Faculty of Education prepares its students to develop key competencies for the teaching process.

The majority of students agreed that the studies at UKZ enabled their preparation as a teacher. The study programs offered by the Faculty of Education such as primary and preschool program prepare the graduate students for the labor market.

The UKZ Faculty of Education offers many courses that train and develop students professionally.

Suggestions based on the results of the present study are as follows:

University "Kadri Zeka" respectively Faculty of Education should offer more courses in all areas of the current curriculum so that graduate students can effectively implement the new school curriculum.

The Professors of the UKZ Faculty of Education should provide materials or create better materials on the current curriculum to ensure that all students receive the information that is necessary for them to be successful in implementing the new school curriculum.

The Faculty of Education students must be in constant search of professional development as well as demand opportunities to expand knowledge about teaching strategies. 


\section{References}

Boshtrakaj, L., Rraci, E., \& Bajrami, K. (2018). Sfidat e zbatimit të reformës kurrikulare në arsimin parauniversitar në Kosovë. Prishtinë: "Rrjeti i Kosovës për Arsim dhe Punësim - KEEN".

Dervodeli, J. (2010). Kurrikula mësimore. Prishtina. Iliria.

Haliti, Sh. (2004). Doracak i mësimit praktik për studentë. Prishtina. Druckart

Hyseni, H. (2005). Zhvillimi, zbatimi dhe vlerësimi i kurrikulit. Prishtina: Kosova Education Center.

Kosovo Pedagogical Institute. (2016). Udhëzues për udhëheqjen e zbatimit të kurrikulës në shkollë, Prishtina.

Mehmeti, S., Buleshkaj, O., \& Lynn, D. (2013). Seminari dy mësimdhenia dhe të mësuarit. Prishtinë: BEP.

MEST. (2013). Formative assessment. Prishtina: Kosovo Basic Education Program

MEST. (2016a). Korniza për sigurim të cilësisë së performancës së shkollës në Kosovë. Institute of Pedagogical Studies. Prishtina.

MEST. (2016b). Kosovo Curriculum; Core Curriculum for Pre-Primary Grade and Primary Education In Kosovo; (Grades 0, I, II, III, IV and V) (revised). "Blendi". Prishtina

MEST. (2016c). Udhëzues për zbatimin e kurrikulës. Institute of Pedagogical Studies. Prishtina.

MEST. (2017). Risitë që i sjell kurrikula e re në arsimin parauniversitar. Prishtina.

Nishku, A., Zenelaj, F., Daci, J., Gjokutaj, M., Hamza, M., Xhafka, N. (2006). Kurrikuli shkollor. Institute of Pedagogical Studies. Prishtina.

Question Pro. (2020). Quantitative research: Definition, methods, types and examples." Retrieved from https://www.questionpro.com/blog/quantitative-research/.

Shimillesha, P. (1988). Pedagogjia, Enti i teksteve dhe i mjeteve mësimore. Prishtina.

University of Kadri Zeka (2016). Self-Evaluation report. Gjilan.

University of Kadri Zeka (2021). Self-Evaluation report. Gjilan.

University of Prishtina/Faculty of Education. (2004). Practical learning- A handbook for students of the Faculty of Education-Primary Program. The project for training Kosovar teachers. Prishtina.

University of Prishtina/Faculty of Education. (2004). Practical learning- A handbook for students of the Faculty of Education-Preschool Program. The project for training Kosovar teachers. Prishtina.

Vojka-Ismajli, H. (2012). Teknologja mësimore dhe të menduarit kritik. Libri Shkollor. Prishtina. 


\section{Appendices}

\section{Questionnaire}

Dear graduate students, through this questionnaire we would like to receive your opinions regarding your preparation for the implementation of the new school curriculum in your teaching. It is thought that you can best assess the preparation or non-preparation of students to work according to the new curriculum, so we believe that your answers will help us ascertain the impact of the Faculty of Education in preparing its graduates for the implementation of the new school curriculum.

I appreciate your cooperation!

\section{Respondent details:}

Gender: $\quad$ Female

Graduation time: Academic year 2016/17; 2017/18; 2018/19; 2019/20

Duration of studies: $\quad 4$ years $\quad 5$ years $\quad 6$ years

Are you employed?: $\quad$ Yes-teacher; $\quad$ No; $\quad$ Yes-different profession

Program: Preschool Primary

2. Studies at the UKZ Education Faculty helped me to develop key competencies for the teaching process

Strongly disagree

Disagree

I don't know

Agree

Strongly agree

3. The duration of studies for the preparation of preschool / primary teachers enabled my preparation as a teacher

Strongly disagree

Disagree

I don't know

Agree

Strongly agree

4. Do you think that the study program offered by the faculty has prepared you for the labor market?

Strongly disagree

Disagree

I don't know

Agree

Strongly agree

5. The study program has provided me with key competencies from the Kosovo Curriculum Framework - KCF

Strongly disagree

Disagree 
I don't know

Agree

Strongly agree

6. Which of the study program courses are the main courses of your training and professional development?

1.Learning theory;

2. Pedagogical Practice;

3. Communication in education;

4. Curriculum development;

5. Assessment in education;

6. Working with Gifted and Talented Children;

7. Learning difficulties;

8. Inclusive education;

9. Mathematics teaching methodology;

10. Albanian language methodology;

11. Basics of social sciences with methodology;

12. Basics of natural sciences with methodology;

13. Classroom management and discipline;

14. All of them

7. Do you think that the above-mentioned courses are sufficient for your preparation in the implementation of the KCF?

a. Yes

b. To some extent

c. No

8. What is your overall evaluation of the quality of the study programs you have attended / completed? -1 = worst; 5 = best
1
3
4
5

9. The literature used by the professors is appropriate for your training and professional development
a. Yes
b. To some extent
c. No 